stances removes one of the objections to the belief that this dual system is a universally important effector of the vertebrate immunological apparatus.

We thank Mr J. Hodges for technical assistance. B. L. ReYNolds

Department of Microbiology, D. ROWLEY

University of Adelaide,

South Australia.

Received December 3, 1968; revised February 3, 1969.

${ }^{1}$ Muschel, L. H., and Gustafson, L., J. Bact., 95, 2010 (1968),

${ }^{2}$ Amano, T., Inai, S., Seki, Y., Kashiba, S., Fujikawa, K., and Nishimura, S., Med.J.Osaka Univ, 4, 401 (1954).

s Allen, D. E., Baker, D. J., and Gillard, R. D., Nature, 214, 906 (1967).

- Repaske, R., Biochim. Biophys. Acta, 30, 225 (1958).

${ }^{5}$ Gray, G. W., and Wilkinson, S. G., J. Gen. Microbiol., 39, 385 (1965).

${ }^{6}$ Lieve, L., Biochem. Biophys. Res. Commun.,21, 290 (1965).

? Burton, A. J., and Carter, H. E., Biochemistry, 3, 411 (196t).

${ }^{8}$ Rowley, D., and Turner, K. J., Nature, 217, 657 (1968).

\section{Aromatic Amines and Parkinson's Disease}

BECAUSE most of the previous work published on aromatic amines in relation to Parkinson's disease was on either dopamine $^{1-8}$, tyramine $e^{9,10}$ or tryptamine ${ }^{11}$, and was only qualitative or semi-quantitative, we thought it would be of value to carry out a quantitative analysis of all three amines in the urine of normal and Parkinsonian patients. Because of the different aetiologies, we restricted our study to the idiopathic type of the disease-paralysis agitans. Our methods were chiefly fluorimetric and the results were reproducible. Dopamine was measured by a slightly modified method of Sourkes and Murphy ${ }^{12}$, tryptamine by the method of Sjoerdsma et al. ${ }^{13}$ and free tyramine by ethyl acetate extraction of alkaline urine, followed by paper chromatography, location, extraction of the area of paper and nitroso-naphthol fluorescence read spectrophotofluorimetrically.

Our results (Table 1) show a significantly higher level of excretion of all three amines in Parkinsonian urine than in control urine. Furthermore, there is a relationship between the concentration of tyramine and the severity and extent of symptoms (Table 2). Variation with the severity of symptoms was not evident for dopamine or tryptamine, but this may have been because of the closer absolute figures relating to patients and controls. Larger populations would be necessary to examine this point further.

Our results confirm previous work. The wide range of Hrunary tyramine concentrations found (A. A. Boulton, personal communication) in Parkinson's disease may be caused by the relative numbers of severe and mild cases (as defined in Table 2). The fact that all three amines

Table 1. URINARX AROMATIC AMINES, IN NORMAL CON'RROLS AND IDIOPATHIC PARKINSON'S DISEASF

$\begin{array}{ccccc}\text { Subjects } & \text { Dopamine } & \begin{array}{c}\text { Trypt- } \\ \text { amine }\end{array} & \begin{array}{c}p \text {-Tyr- } \\ \text { amine }\end{array} & \begin{array}{c}\text { Creatinine } \\ \mathrm{g} / 24 \mathrm{~h}\end{array} \\ \text { Normal controls } & \text { Mean } 127 & 60 & 400 & 1.385 \\ 15 & \text { S.E.M. } 8.2 & 5.4 & 33.5 & 0.36 \\ \text { Idiopathic Parkinson's } & \text { Mean } 150 & 80 & 505 & 1.363 \\ 19 & \text { S.E.M. }{ }^{7.9} & 7.8 & 33 & 0.31 \\ \text { Significance } & P<0.05 & P<0.05 & P<0.05 & P<0.9>0.8\end{array}$

Results are expressed as $\mu \mathrm{g} / \mathrm{g}$ creatinine in $24 \mathrm{~h}$ specimens.

Table 2. FREE $p$-TYRAMINE IN PARKINSON'S DISEASE

Normal
15
400
33.5

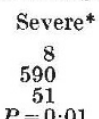

Mild $\uparrow$

Number of subjects

Mean
S.E.M.

$33 \cdot 5$

$P=\stackrel{51}{P=0} \cdot 01$

11
443

Results are in $\mu \mathrm{g} / \mathrm{g}$ creatinine.

* Severe cases had both tremor and rigidity.

+ Mild cases had tremor or rigidity but not both. are excreted in greater concentrations in this condition may suggest that some common enzyme or pathryay is involved in the overall mechanism of decarboxylation or depletion of stores.

We thank Dr K. J. Zilkha for providing us with urine specimens and both him and Professor R. H. S. Thompson for fruitful discussions. One of us (A. H. K.) is on extended study leave from the Institute of Clinical Analysis, Medical Research Centre, College of Medicine, Bagdad.

Ivor SMITH

Courtauld Institute,

A. H. Kellow

Middlesex Hospital,

London WI.

Received November 4, 1968; revised January 8, 1969 .

${ }^{1}$ Barbeau, A., Archives of Neurology, 4, 97 (1961).

2 Barbeau, A., Union Médicale du Canada, 88, 262 (1959).

${ }^{3}$ Barbeau, A., Neurology, 10, 446 (1960).

${ }^{4}$ O'Reilly, S., Loncin, M., and Cooksey, B., Neurology, 15, 980 (1965).

- Barbeau, A., Murphy, G. F., and Sourkes, T. L., Science, 133, 1706 (1961).

- Barbeau, A., Sourkes, T. L., and Murphy, G. F., p. 247 (George et Masson, Qèneve et Paris, 1962).

Bernheimer, H., and Hornykiewicz, O., Arch. Exp. Pathol. Pharmacol., 247, 305 (1964).

Barbeau, A., De Groot, J. A., Joly, J. G., Raymond-Tremblay, D., and Donaldson, J., Rev. Canad. Biol., 22, 469 (1963).

- Takesada, M., Kakimoto, Y., Sano, I., and Kaneko, S., Nature, 199, 203 (1963).

${ }^{10}$ Boulton, A. A., Majer, J. R., and Pollitt, R. J., Nature, 215, 132 (1967).

${ }^{11}$ Kuehl, jun., F. A., Vandenheuvel, W. J. A., and Ormond, R. E., Nature, 217,136 (1968)

${ }^{12}$ Sourkes, T. L., and Murphy, G. F., Methods in Med. Res. (edit. by Quastel, J. H.), 9, 147 (Year Book Medical Publishers, 1961).

${ }^{23}$ Sjoerdsma, A., Oates, J. A., Zaltzman, P., and Udenfriend, S., J. Pharmacol. Exp. Therap.,126, 217 (1959).

\section{Differential Immune Lysis of Erythroblasts}

WE have investigated the stage in erythroblast maturation at which erythrocyte membrane antigens first appear, using an antiserum which lysed rabbit erythrocytes. Mature acidophilic erythroblasts were lysed with a lower concentration of antiserum (complement in excess) than were the less mature basophilic cells.

The antiserum was prepared by the repeated injection into a goat of washed rabbit erythrocytes, the buffy coat of which had been removed. The washed marrow cell suspension prepared as previously described ${ }^{1}$ was made up to twenty times the packed cell volume with NKM ( $\mathrm{NaCl}$ $0.154 \mathrm{M}$, $\mathrm{KCl} 0.005 \mathrm{M}$ and $\mathrm{MgCl}_{2} 0.005 \mathrm{M}$ ). Hyland dried guinea-pig complement (Hyland Division, Travenol Corp., Los Angeles) was made to the original volume with saline $\left(\mathrm{NaCl} 0.145 \mathrm{M}, \mathrm{MgCl}_{2} 0.00039 \mathrm{M}, \mathrm{CaCl}_{2} 0.00031 \mathrm{M}\right.$ ) and then diluted ten-fold with NKM. Complement, $0.5 \mathrm{ml}$., was mixed with $0.5 \mathrm{ml}$. of antiserum of the desired dilution (with NKM), followed by $1 \mathrm{ml}$. of the marrow cell suspension. The mixture was incubated in a siliconized $12 \mathrm{ml}$. conical centrifuge tube for $1 \mathrm{~h}$ at $37^{\circ} \mathrm{C}$. The degree of lysis was measured by differential counts of smears of the erythroid cells which remained. The smears were stained with benzidine and counter-stained with Giemsa solution. The long diameter of the erythroblasts was measured with a scale in the eyepiece and the colour of the cytoplasm scored 0 and 5 when blue or yellow respectively; intermediate colours were given intermediate scores according to the criteria previously described ${ }^{1}$.

Table 1 shows a typical series of differential counts of erythroid cells after lysis by a series of dilutions of antiserum. With the highest concentration of antiserum, nearly all the erythroblasts which remained unlysed were 0 scoring cells, that is, basophilic. With progressive dilutions of the antiserum, the proportion of acidophilic cells (scoring $2-5$ ) increased. 